\title{
Mutant huntingtin Impairs the Post-Golgi Trafficking of Brain-Derived Neurotrophic Factor But Not Its Val66Met Polymorphism
}

\author{
Daniel del Toro, ${ }^{1}$ Josep M. Canals, ${ }^{1,}$ Silvia Ginés, ${ }^{1}$ Masami Kojima, ${ }^{2,3}$ Gustavo Egea, ${ }^{1}$ and Jordi Alberch ${ }^{1}$ \\ ${ }^{1}$ Departament de Biologia Cel·lular i Anatomia Patològica, Facultat de Medicina, Institut d'Investigacions Biomèdiques August Pi i Sunyer, Universitat de \\ Barcelona, 08036 Barcelona, Spain, ${ }^{2}$ Research Institute for Cell Engineering, National Institute of Advanced Industrial Science and Technology, Ikeda, \\ Osaka 563-8577, Japan, and ${ }^{3}$ Solution Oriented Research for Science and Technology, Japan Science and Technology Agency, Kawaguchi, Saitama, 332- \\ 0012, Japan
}

Brain-derived neurotrophic factor (BDNF) polymorphism is associated with the pathophysiology of several neurodegenerative disorders, including Huntington's disease. In view of these data and the involvement of huntingtin in intracellular trafficking, we examined the intracellular transport and release of Val66Val BDNF (Val-BDNF) and Val66Met BDNF (Met-BDNF) in transfected striatal knock-in cells expressing wild-type or mutant full-length huntingtin. Colocalization studies with specific markers for endoplasmic reticulum showed no differences between the Val-BDNF and Met-BDNF and were not modified by mutant huntingtin. However, post-Golgi trafficking was altered by mutant huntingtin dependent on the BDNF form. Thus, fluorescence recovery after photobleaching (FRAP) and inverse FRAP analysis showed retention of Met-BDNF in the Golgi apparatus with respect to Val-BDNF in wild-type cells. Strikingly, mutant huntingtin diminished post-Golgi trafficking of Val-BDNF, whereas Met-BDNF was not modified. Accordingly, a reduction in the number of transport vesicles was only observed in mutant huntingtin cells transfected with Val-BDNF but not Met-BDNF. Moreover, mutant huntingtin severely affected the KCl-evoked release of Val-BDNF, although it had little effect on Met-BDNF regulated release. The constitutive release of Val-BDNF or Met-BDNF in mutant cells was only slightly reduced. Interestingly, mutant huntingtin only perturbed post-Golgi trafficking of proteins that follow the regulated secretory pathway (epidermal growth factor receptor or atrial natriuretic factor), whereas it did not change those that follow the constitutive pathway $\left(\mathrm{p} 75^{\mathrm{NTR}}\right)$.

We conclude that mutant huntingtin differently affects intracellular transport and release of Val-BDNF and Met-BDNF. In addition, our findings reveal a new role for huntingtin in the regulation of the post-Golgi trafficking of the regulated secretory pathway.

Key words: Huntington's disease; neurotrophin; vesicular transport; trans-Golgi network; p75; EGFR

\section{Introduction}

Brain-derived neurotrophic factor (BDNF) plays a critical role in the pathophysiology of different neurodegenerative diseases, such as Huntington's disease (HD) (Zuccato et al., 2001; Canals

Received April 20, 2006; revised 0ct. 25, 2006; accepted 0ct. 26, 2006.

This study was supported by Ministerio de Educación y Ciencia Grants SAF2005-00314 (J.A.), SAF2005-00147 (J.M.C.), and BMC2003-1064 (G.E.), Redes Temáticas de Investigación Coorporativa Grants G03/167 and G03/210 (Ministerio de Sanidad y Consumo, Spain), Fundació La Caixa, and Ministry of Education, Culture, Science and Technology (18021042), Japan. D.d.T. is a fellow from the Spanish Ministerio de Educación y Ciencia. We thank M. Teresa Muñoz and Ana López for technical assistance, Dr. Maria Calvo from the confocal microscopy unit of the Serveis Científico-Tècnics (Universitat de Barcelona) for her support and advice with all confocal techniques, and Dr. Baldomero Oliva for advice on prodomain modeling. We also express our appreciation to Dr. Francesc Tebar for epidermal growth factor receptor construct, Dr. Edwin S. Levitan for atrial natriuretic factor construct, Dr. Jennifer Lippincott-Schwartz for galactosyltransferase construct, and Dr. Roman Polishchuck for p75 vector. We thank Dr Marcy MacDonald for striatal knock-in cells, Dr. Evan Y. Snyder for C17.2 cells, and Dr. William Freed for M213 cells. We thank the Reagent Resource Bank of the Hereditary Disease Foundation for exon $1 \mathrm{htt}$ constructs and Dr. Francis S. Lee and Dr. Zhe-Yu Chen for the kind of gift of dual epitope-tagged BDNF constructs. We also express our appreciation to Dr. Fréderic Saudou and Dr. Sandrine Humbert for full-length wild-type and mutant htt constructs.

Correspondence should be addressed to Dr. Jordi Alberch, Departament de Biologia Cel·lular i Anatomia Patològica, Facultat de Medicina, Institut d'Investigacions Biomèdiques August Pi i Sunyer, Universitat de Barcelona Carrer Casanova 143, E-08036 Barcelona, Spain. E-mail: alberch@ub.edu.

D01:10.1523/JNEUROSCI.3873-06.2006

Copyright $\odot 2006$ Society for Neuroscience $\quad 0270-6474 / 06 / 2612748-10 \$ 15.00 / 0$ et al., 2004). HD is a neurodegenerative disorder caused by a multiple CAG expansion in exon 1 of huntingtin (htt) gene (Kremer et al., 1994), producing a significant dysfunction and neural death, especially in the medium spiny neurons of the striatum. $\mathrm{Htt}$ is a ubiquitously expressed large protein that participates in a plethora of functions, including clathrin-mediated endocytosis, vesicle transport, transcriptional regulation, and cell survival (for review, see Harjes and Wanker, 2003; Cattaneo et al., 2005). In relation to BDNF, htt enhances the transcription of BDNF by the inhibition of the neuron restrictive silencer element (Zuccato et al., 2003) and promotes the transport of BDNF-containing vesicles along microtubules (Gauthier et al., 2004). Thus, the mutation of htt produces a reduction in BDNF expression (Ferrer et al., 2000; Zuccato et al., 2001) and release (Gauthier et al., 2004), which in turn affect the survival action of BDNF on striatal neurons (Canals et al., 2004).

As in all neurotrophins, BDNF is synthesized as a protein precursor composed by two domains, the prodomain and the BDNF domain (Seidah et al., 1996). The BDNF prodomain has an important role in the intracellular traffic of BDNF, promoting the sorting of proBDNF to the regulated secretory pathway be- 
cause of its interaction with sortilin at the trans-Golgi network (TGN) (Chen et al., 2005). The sorting of BDNF to the regulated secretory pathway is impaired by a BDNF polymorphism consisting in a valine to methionine substitution at codon 66 in the prodomain (Val66Met BDNF) (Chen et al., 2004), reducing the amount of secreted BDNF after neural cell depolarization (Egan et al., 2003; Chen et al., 2004).

The characterization of this BDNF polymorphism has also highlighted the importance of this neurotrophin in different neuropsychiatric disorders. In fact, several studies have associated this polymorphism with increased susceptibility to anorexia nervosa (Ribases et al., 2003), obsessive-compulsive disorders (Hall et al., 2003), eating disorders (Friedel et al., 2005), depression (Sen et al., 2003), schizophrenia (Skibinska et al., 2004), Alzheimer's disease (Ventriglia et al., 2002), and Parkinson's disease (Momose et al., 2002).

We reported recently that heterozygous patients with HD carrying Val66Met BDNF (Met-BDNF) allele have a later age of onset compared with homozygous Val66Val BDNF (Val-BDNF) patients (Alberch et al., 2005). These data and the emerging properties of htt in intracellular trafficking prompted us to study the role of mutant htt (mhtt) in the intracellular transport of ValBDNF and Met-BDNF in striatal knock-in cells that express wildtype (wt) full-length htt (with 7Q, wt cells) or full-length mhtt (with $111 \mathrm{Q}$, mhtt cells). Here, we also report that mhtt impairs post-Golgi trafficking of Val-BDNF but not of Met-BDNF, which in turn produces an impairment of Val-BDNF-containing vesicles and a reduction of the $\mathrm{KCl}$-evoked release of Val-BDNF. In addition, the results show that htt participates in the post-Golgi transport of proteins that follow the regulated secretory pathway.

\section{Materials and Methods}

Reagents and antibodies. Anti-giantin antibody was kindly supplied by H. P. Hauri (Basel, Switzerland), anti-calnexin peptide 4 (residues 555573) was from the Bergeron Laboratory (Montreal, Quebec, Canada) (Wada et al., 1991), and anti-secretogranin II was from Biodesign (Saco, ME). Anti-BDNF antibody was from Alomone Labs (Jerusalem, Israel), anti-epidermal growth factor receptor (EGFR) was from Santa Cruz Biotechnology (Santa Cruz, CA), and anti-htt MAB 2166 was from Chemicon (Temecula, CA). Fluorescent cyanine 3 (Cy3) (anti-rabbit) and Alexa 647 (anti-mouse and anti-rabbit) secondary antibodies were from Invitrogen (Carlsbad, CA) and rhodamine-conjugated anti-mouse antibody was from Jackson ImmunoResearch (West Grove, PA). Lipofectamine 2000 was from Invitrogen.

DNA constructs. The human BDNF and its Val66Met polymorphism subcloned into pCDNA3.1hygro expression vector (Invitrogen) with hemagglutinin epitope tag at $3^{\prime}$ and FLAG epitope tag at $5^{\prime}$ was kindly supplied by Dr. Francis S. Lee (Weill Medical College of Cornell University, New York, NY) (Chen et al., 2004). BDNF and its variant Val66Met polymorphism subcloned into enhanced green fluorescent protein (eGFP)-N1 plasmid (Clontech, Palo Alto, CA) was described by Egan et al. (2003). The p $75^{\mathrm{NTR}}$ receptor fused to GFP was kindly supplied by Dr. Roman Polishchuck (Consorzio Mario Negri Sud, Santa Maria Imbaro, Italy). EGFR fused to GFP was generously supplied by Dr. Francesc Tebar (Universitat de Barcelona, Barcelona, Spain) (Carter and Sorkin, 1998), atrial natriuretic factor (ANF) fused to GFP was a gift from Dr. Edwin S. Levitan (University of Pittsburgh, Pittsburgh, PA) (Burke et al., 1997), and galactosyltransferase fused to yellow fluorescent protein (GT-YFP) was kindly supplied by Dr. Jennifer Lippincott-Schwartz (National Institutes of Health, Bethesda, MD). Full-length 17Q htt (FL-17Q-htt) and full-length 75Q htt (FL-75Q-htt) was a gift from Drs. Fréderic Saudou and Sandrine Humbert (Institut Curie, Orsay, France) (Gauthier et al., 2004). Htt exon1 with 25Q (exon1-25Q-htt) and 103Q (exon1-103Qhtt) was generously provided by Dr. George M. Lawless (Cure HD Initiative, Reagent Resource Bank of the Hereditary Disease Foundation, New York, NY).

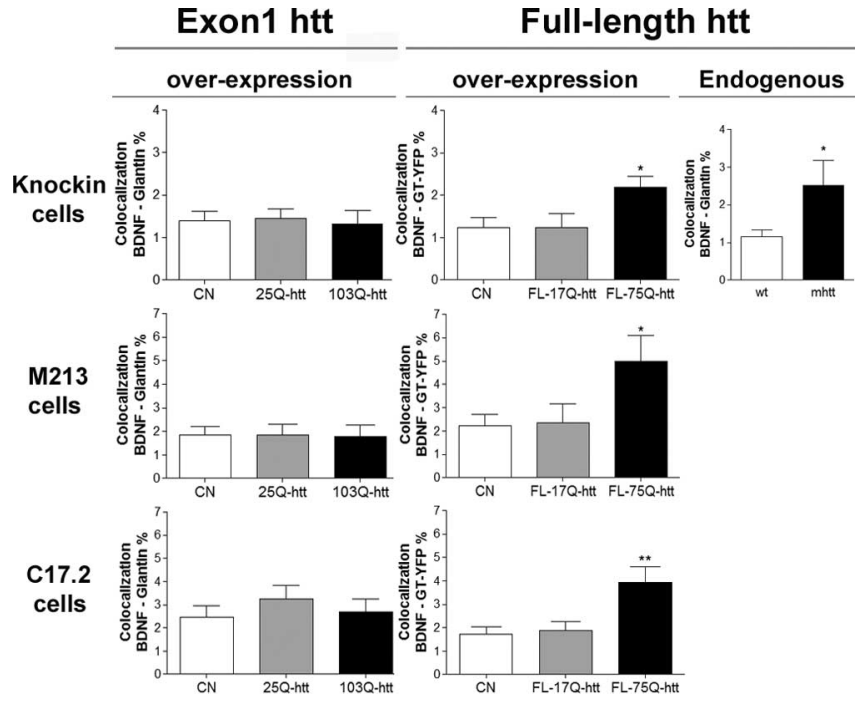

Figure 1. Full-length, but not exon1, mhtt increases BDNF accumulation in Golgi. Wt cells and M213 and C17.2 cells were transfected with GFP, exon1-25Q-htt of exon1-103Q-htt fused to GFP (Exon1 section), or with GT-YFP or GT-YFP plus FL-17Q-htt or FL-75Q-htt (Full-length htt overexpression section). Colocalization studies of endogenous BDNF with giantin showed no difference between GFP-expressing cells and exon1-025-htt or exon1-1030-htt. In contrast, colocalization of endogenous BDNF with GT-YFP showed an increased accumulation of BDNF in the Golgi apparatus in cells transfected with FL-75Q-htt with respect to FL-17Q-htt- or GT-YFPtransfected cells. mhtt cells showed an increased BDNF accumulation in the Golgi apparatus compared with wt cells (Full-length htt endogenous section). ${ }^{*} p<0.05 ;{ }^{* *} p<0.01$.

Striatal knock-in wt and mhtt cells and M213 and C17.2 cell culture and transfection. To study the effect of htt in the intracellular transport of BDNF, we used the following cell lines: striatal knock-in cells stably expressing full-length htt (7Q/7Q) or full-length mhtt (111Q/111Q) established from HdhQ111 knock-in mice (Trettel et al., 2000); the M213 cells, conditionally immortalized striatal derived neural stem cells (Giordano et al., 1993); and the C17.2 cells, a multipotent neural stem cell line generated by retrovirus-mediated v-myc transfer into murine cerebellar progenitor cells (Ryder et al., 1990). All cell lines were transfected using Lipofectamine 2000 as instructed by the manufacturer.

Immunocytochemical staining and confocal microscopy analysis. Twenty-four hours after transfection, cells were fixed in $4 \%$ paraformaldehyde for $10 \mathrm{~min}$ and $0.2 \mathrm{M}$ glycine for $20 \mathrm{~min}$ and permeabilized in $0.1 \%$ saponin for $10 \mathrm{~min}$. Blocking was done in 1\% BSA in PBS for $1 \mathrm{~h}$. Specimens were incubated with primary antibodies: anti-BDNF (1:50), anti-giantin (1:500), anti-calnexin (1:100), anti-secretogranin II (1:100), anti-EGFR (1:100), and anti-htt (1:100). Afterward, specimens were incubated with subtype-specific fluorescent secondary antibodies: $\mathrm{Cy} 3$ and rhodamine-conjugated anti-mouse (1:300) and Alexa 647 (1:100). Double-stained cells were examined by confocal microscopy using Leica (Mannheim, Germany) TCS SL laser scanning confocal spectral microscope with argon and helium-neon lasers attached to a Leica DMIRE2 inverted microscope. Images were taken using $63 \times$ numerical aperture (NA) objective with $4 \times$ digital zoom and standard (one Airy disc) pinhole. For each cell, the entire three-dimensional stack of images was obtained by the use of the $\mathrm{Z}$ drive present in the Leica TCS-SL microscope, and the size of the optical image was $0.5 \mu \mathrm{m}$. The colocalization was measured using the freeware NIH ImageJ version 1.33 by Wayne Rasband (National Institutes of Health, Bethesda, MD). Briefly, for each cell stack, the cell area was delineated, and the total number of doublepositive pixels for BDNF/EGFR and a specific subcellular region staining for each slice were summed. This value was divided by the number of total positive pixels for BDNF/EGFR in the stack and multiplied by 100 . For BDNF-eGFP colocalization studies, $70-80$ cells were randomly selected, whereas for endogenous BDNF and EGFR colocalization, 20-25 cells were randomly selected.

Fluorescence recovery after photobleaching and inverse fluorescence recovery after photobleaching experiments. Fluorescence recovery after pho- 
A
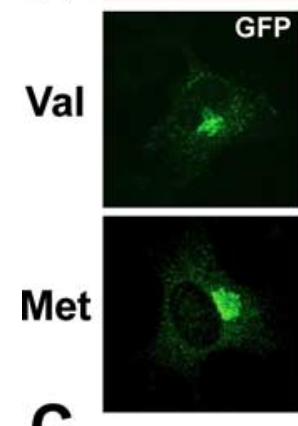

C

Val
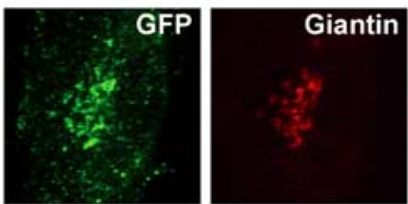

Met

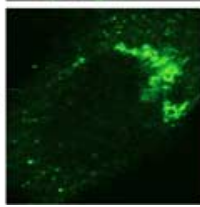

wt
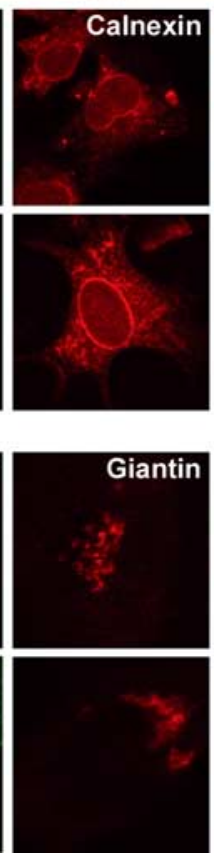
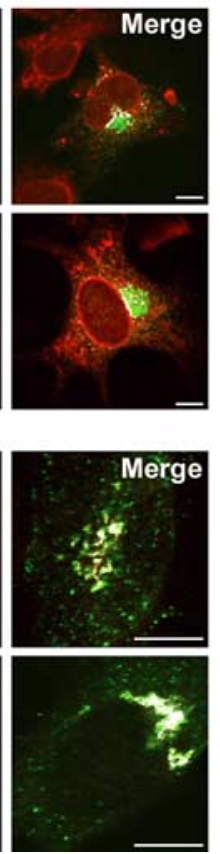

mhtt
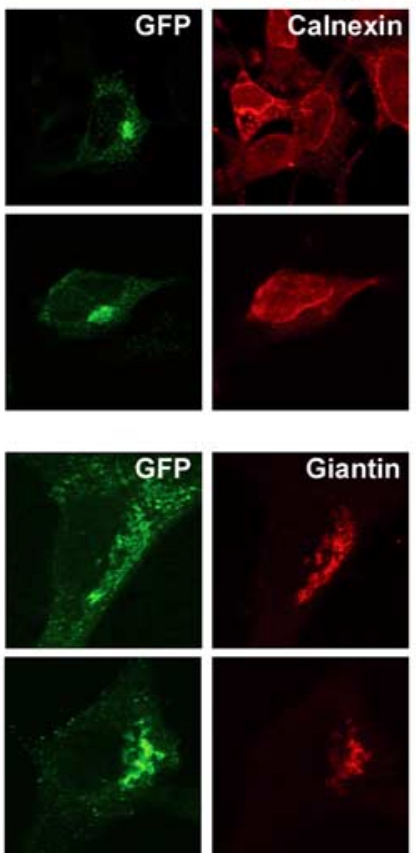
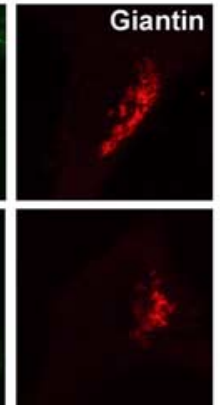

B
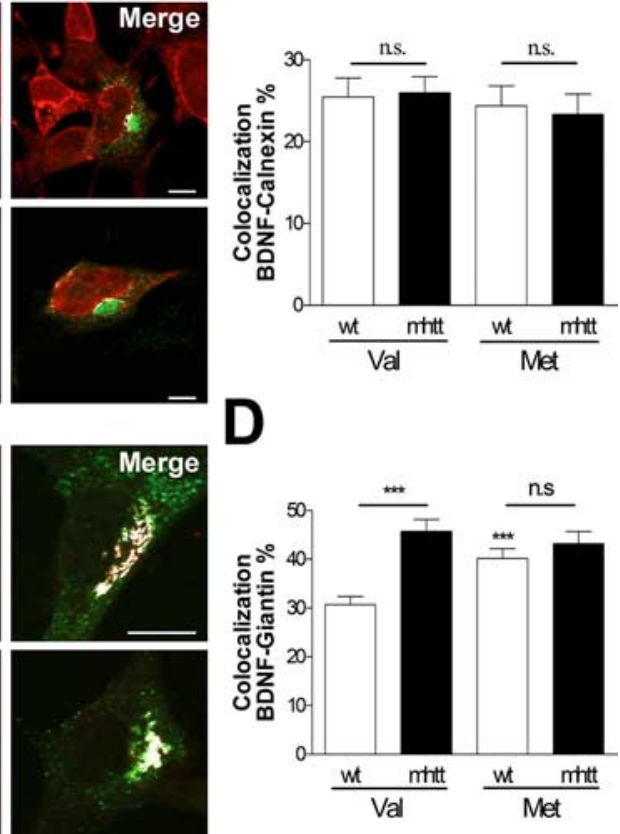

Figure 2. In mhtt cells, Val-BDNF but not Met-BDNF is retained at the Golgi apparatus. $A, B$, Colocalization of Val-BDNF or Met-BDNF with calnexin in wt and mhtt cells did not show any difference between all conditions. C, D, Colocalization of Val-BDNF or Met-BDNF with giantin, a Golgi marker, revealed a higher colocalization of Val-BDNF in mhtt cells compared with wt cells, although these effects were not observed in mhtt cells expressing Met-BDNF compared with wt cells. Results are represented as a mean \pm SEM determined from analysis of three independent experiments [not significant (n.s.), $p>0.05 ;{ }^{* * *} p<0.001$ vs Val-BDNF in wt cells]. Scale bar, $8 \mu \mathrm{m}$.

tobleaching (FRAP) and inverse FRAP (iFRAP) experiments were performed using the Leica confocal microscope mentioned above equipped with an incubation system with temperature and $\mathrm{CO}_{2}$ control. Cells, $4 \times$ $10^{5}$, were seeded to $35 \mathrm{~mm}$ plate (Nunc, Roskilde, Denmark) containing a glass coverslip of $22 \mathrm{~mm}$ (Micro cover glass; Electron Microscopy Sciences, Fort Washington, PA). After $24 \mathrm{~h}$, cells were transfected with $4 \mu \mathrm{g}$ of either Val-BDNF-eGFP or Met-BDNF-eGFP constructs. For FRAP experiments $24 \mathrm{~h}$ after transfection, the glass coverslip was mounted in the video confocal chamber, keeping the cells at $33^{\circ} \mathrm{C}$, whereas for iFRAP experiments, cells were before incubated for $2 \mathrm{~h}$ in media at $20^{\circ} \mathrm{C}$ (last hour in the presence of $0.1 \mathrm{mg} / \mathrm{ml}$ cycloheximide).

For visualization of eGFP, images were acquired using $63 \times$ oil immersion objective lens (numerical aperture, 1.32), $488 \mathrm{~nm}$ laser line, excitation beam splitter RSP 500, 500-600 nm emission range detection, and the confocal pinhole set at 2-3 Airy units to minimize changes in fluorescence efficiency attributable to eGFP proteins moving away from the plane of focus.

For FRAP experiments, the whole Golgi area was photobleached using 40 scans with the $488 \mathrm{~nm}$ laser line at full power. To correctly detect the fast component of the recovery, the first 30 images were taken during each half of a second, and the rest were taken each $2 \mathrm{~s}$ during $10 \mathrm{~min}$. For iFRAP experiments, the whole cytoplasm area of the transfected cell was photobleached using 80 scans with the $488 \mathrm{~nm}$ laser line at full power. Afterward, images were collected in stream mode each $5 \mathrm{~s}$ during $20 \mathrm{~min}$.

All FRAP and iFRAP experiments were corrected and normalized using the equation described by Phair and Misteli (2000) and Dundr et al. (2002), respectively (supplemental data, available at www.jneurosci.org as supplemental material). FRAP curves were fitted assuming one-phase exponential association equation, whereas iFRAP curves were modeled equally well with a two-phase exponential decay equation (supplemental Fig. 1, available at www.jneurosci.org as supplemental material). Fifteen cells per condition were randomly selected for FRAP experiments, whereas six to nine cells per condition were randomly selected for iFRAP experiments.

Video microscopy experiments and analysis. Video microscopy experiments were done $24 \mathrm{~h}$ after transfection. Cells were transfected with either Val-BDNF-eGFP or Met-BDNF-eGFP as described for FRAP experiments. One day after, the glass coverslip was mounted in the video confocal chamber of the confocal microscope, keeping the cells at $33^{\circ} \mathrm{C}$. Images were collected in stream mode using the $63 \times$ oil immersion objective with $4 \times$ of digital zoom, each second during $1 \mathrm{~min}$. The pinhole was set to $350 \mu \mathrm{m}$, and the laser power was to $10 \%$. All vesicles in each cell were selected and tracked using the particle-tracking software Diatrack version 3.0 (Semasopht, Chavannes, Switzerland) measuring the mean velocity of each vesicle. The mean velocity of each vesicle was calculated over the $1 \mathrm{~min}$ of acquisition time. In this way, the length of a vesicle trajectory, computed as the sum of the lengths of displacement vectors composing it, was divided by the lifetime of the vesicle. A displacement vector is the distance covered by one vesicle between two successive images of the sequence. The Cartesian coordinates of the center of the vesicles were used to calculate dynamic parameters as described by Gauthier et al. (2004). To calculate the diffusion pattern of Val-BDNF and Met-BDNF vesicles in wt and mhtt cells, the squared distance of each vesicle from its position at time $0-10 \mathrm{~s}$ was averaged and reported in a graph as a function of time. Ten to 15 cells per condition were randomly selected for video microscopy experiments.

ELISA assay. Fifty thousand cells per well were seeded to 24-well plates. After $24 \mathrm{~h}$, cells were transfected with $0.8 \mu \mathrm{g}$ of dual-epitopetagged Val-BDNF and Met-BDNF to avoid GFP interference with the ELISA method. At $24 \mathrm{~h}$ later, cells were washed with PBS, and 500 $\mu 1 /$ well N2 medium was added. The conditioned media was collected after $24 \mathrm{~h}$ of incubation with N2 medium and used as a measure of constitutive secretion. To determine regulated secretion, cells were washed twice with PBS, followed by 15 min incubation at $33^{\circ} \mathrm{C}$ with modified Krebs-Ringer-Henseleit buffer with the following composition (in mM): $75 \mathrm{NaCl}, 56 \mathrm{KCl}, 2.6 \mathrm{CaCl}_{2}, 25 \mathrm{HEPES}, 1.2 \mathrm{MgSO}_{4}, 5.6$ glucose, 1 sodium ascorbate, and $1.2 \mathrm{KH}_{2} \mathrm{PO}_{4}$, pH 7.4, as described previously (Chen et al., 2004). The BDNF protein concentrations in the respective media samples were measured using the BDNF Emax immunoassay system (Promega, Madison, WI). Standards and samples were performed in duplicates, and each group contained six independent samples. 


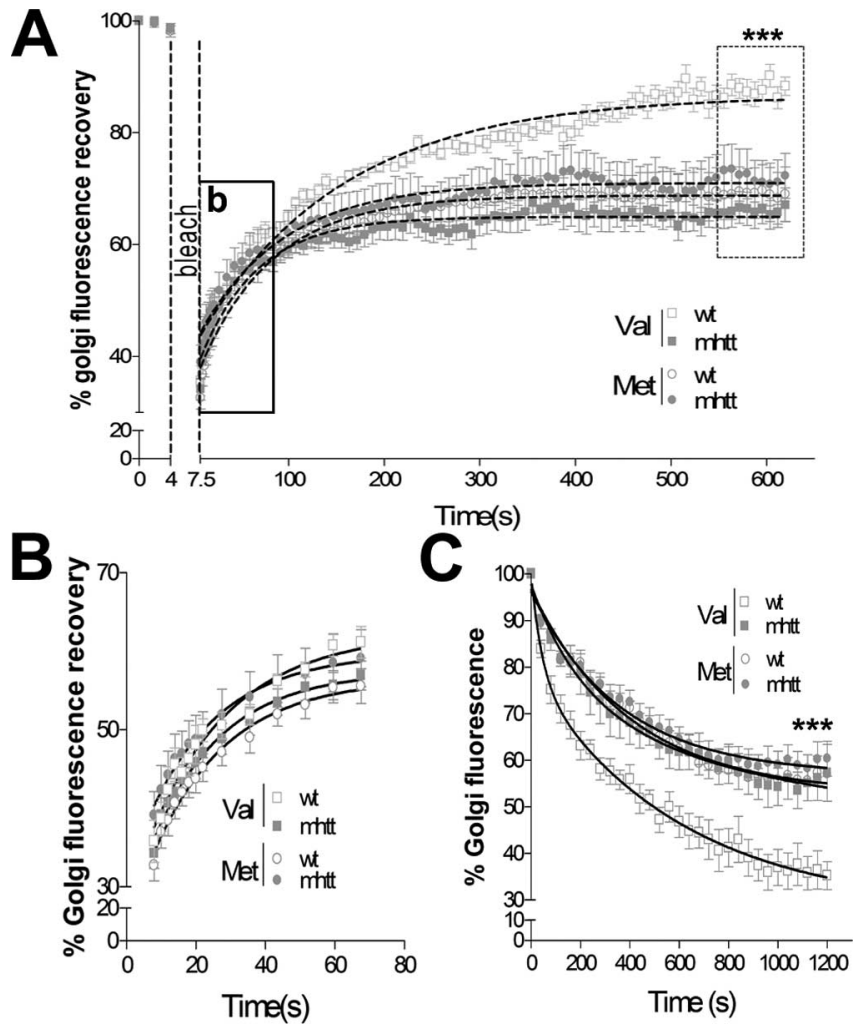

Figure 3. mhtt differentially impairs post-Golgi trafficking of Val-BDNF and Met-BDNF. $A$, FRAP recovery curves, in which the rectangle shows the rapid diffusion between ER-to-Golgi (enhanced region shown in $\boldsymbol{B}$ ) and the dotted rectangle shows the plateau reached in its condition showing a reduced Golgi fluorescence recovery of Val-BDNF in mhtt and Met-BDNF in either wt or mhtt cells compared with Val-BDNF in wt cells. $\boldsymbol{B}$, Graph showing no differences in the earlier transport from ER-to-Golgi between all conditions. C, iFRAP curves showing protein exit as Golgi fluorescence decay. Val-BDNF expressed in mhtt cells as well as Met-BDNF expressed in both cells showed a reduced Golgi exit compared with wt cells expressing Val-BDNF. Results are represented as a mean \pm SEM determined from analysis of three independent experiments. ${ }^{* * *} p<0.001$.

Statistical analysis. For statistical analysis, Prism version 4.0 (GraphPad Software, San Diego, CA) software was used, performing nonparametric one-way ANOVA and Bonferroni's post hoc test. For iFRAP experiments, with two conditions, the nonparametric $t$ test followed by the Mann-Whitney test was used.

\section{Results}

\section{Full-length but not exon $1 \mathrm{mhtt}$ accumulates endogenous} BDNF in the Golgi apparatus

We first analyzed whether full-length or exon1 mhtt affects BDNF intracellular trafficking in different cell lines: striatal knock-in wt cells and M213 and C17.2 cells. In all three lines, colocalization studies revealed an increased colocalization of endogenous BDNF with the Golgi apparatus in the presence of FL-75Q-htt but not in the presence of exon1-103Q-htt (Fig. 1) (supplemental Figs. 2-4, available at www.jneurosci.org as supplemental material). For exon 1 colocalization analysis, cells were transfected with exon1-25Q-htt, exon1-103Q-htt fused to GFP, or with GFP alone (control condition). After $24 \mathrm{~h}$ of transfection, cells were fixed and immunostained against BDNF and giantin. No differences in the colocalization of BDNF with giantin were observed in all cell lines. In the case of full-length htt, because there is not any tag in the vector, we cotransfected FL-17Q-htt and FL-75Q-htt with GT-YFP (which selectively marks the Golgi apparatus, ratio 8:1, respectively) or we transfected with GT-YFP
Table 1. Kinetic values and mobility fractions calculated for FRAP and iFRAP experiments

\begin{tabular}{|c|c|c|c|c|c|c|}
\hline \multirow{2}{*}{$\begin{array}{l}\text { Experimental } \\
\text { condition }\end{array}$} & \multicolumn{3}{|l|}{ ER $\rightarrow$ Golgi } & \multicolumn{3}{|c|}{ Golgi $\rightarrow$ Plasma membrane } \\
\hline & $K$ constant & \multicolumn{2}{|c|}{$\begin{array}{l}T_{1 / 2}(0.69 / \mathrm{K}) \\
(\mathrm{s})\end{array}$} & $\begin{array}{l}\text { Mobile fraction } \\
\%\end{array}$ & $K$ constant & $\begin{array}{l}T_{1 / 2}(0.69 / K) \\
(s)\end{array}$ \\
\hline \multicolumn{7}{|l|}{ Val } \\
\hline wt & \multirow{2}{*}{$\begin{array}{l}0.043 \\
0.049\end{array}$} & \multicolumn{2}{|l|}{16.04} & $88.36 \pm 1.74$ & 0.007 & 97.47 \\
\hline mhtt & & \multicolumn{2}{|l|}{14.08} & $68.05 \pm 3.48^{*}$ & 0.016 & 43.12 \\
\hline \multicolumn{7}{|l|}{ Met } \\
\hline wt & \multirow{2}{*}{$\begin{array}{l}0.045 \\
0.048\end{array}$} & \multirow{2}{*}{\multicolumn{2}{|c|}{$\begin{array}{l}15 \\
14.37\end{array}$}} & \multirow{2}{*}{$\begin{array}{l}69.77 \pm 6.32^{*} \\
7237+4.27^{*}\end{array}$} & 0.013 & 52.55 \\
\hline \multirow[t]{2}{*}{ mhtt } & & & & & 0.011 & 60.26 \\
\hline & \multicolumn{6}{|c|}{ Golgi $\rightarrow$ Plasma membrane } \\
\hline $\begin{array}{l}\text { Experimental } \\
\text { condition }\end{array}$ & \multicolumn{2}{|c|}{ Mobile fraction \% } & $\begin{array}{l}K_{1} \text { con- } \\
\text { stant }\end{array}$ & \multicolumn{2}{|c|}{$K_{2}$ constant } & $T_{1 / 2}(\mathrm{~s})$ \\
\hline \multicolumn{7}{|l|}{ Val } \\
\hline wt & \multirow{2}{*}{\multicolumn{2}{|c|}{$\begin{array}{l}64.74 \pm 3.1 \\
42.65 \pm 6.83^{*}\end{array}$}} & \multirow{2}{*}{$\begin{array}{l}0.0016 \\
0.001\end{array}$} & \multicolumn{2}{|c|}{0.0023} & 236.8 \\
\hline mhtt & & & & 0.005 & & 245.9 \\
\hline \multicolumn{7}{|l|}{ Met } \\
\hline wt & \multirow{2}{*}{\multicolumn{2}{|c|}{$\begin{array}{l}42.83 \pm 4.59^{*} \\
39.63 \pm 4.09^{*}\end{array}$}} & $1.35 e-5$ & \multicolumn{2}{|c|}{0.0025} & 279.4 \\
\hline mhtt & & & $1.65 e-5$ & 0.002 & & 253.1 \\
\hline \multicolumn{7}{|l|}{ p75 } \\
\hline wt & \multirow{2}{*}{\multicolumn{2}{|c|}{$\begin{array}{l}64.97 \pm 5.75 \\
63.16 \pm 4.65\end{array}$}} & 0.0018 & 0.029 & & 265.2 \\
\hline mhtt & & & 0.0014 & 0.001 & & 200.1 \\
\hline EGFR & & & & & & \\
\hline wt & 63.82 & & 0.0013 & 0.015 & & 210.5 \\
\hline mhtt & 35.02 & & 0.0014 & 0.013 & & 185.3 \\
\hline ANF & & & & & & \\
\hline wt & 54.46 & & 0.0013 & 0.002 & & 398.8 \\
\hline mhtt & 22.46 & & $1.27 e-5$ & 0.004 & & 170.3 \\
\hline
\end{tabular}

Top, FRAP studies showing no differences in the transport between the ER to the Golgi apparatus in all experimental conditions (Fig. 3B), whereas total fluorescence values indicated a reduced mobile fraction of Val-BDNF in mhtt cells and Met-BDNF in both wt and mhtt cells $\left({ }^{*} p<0.05\right.$ ) (Fig. 3A). Bottom, iFRAP studies showing a reduced mobile fraction of Val-BDNF in mhtt cells and Met-BDNF in both cells compared with Val-BDNF in wt cells ( ${ }^{*} p<0.05$ vs Val-BDNF in wt cells). In contrast to $\mathrm{p} 75^{\mathrm{NTR}}$, EGFR and ANF expressed in mhtt cells showed a reduced mobile fraction compared with wt cells (Fig. 4) ( ${ }^{\#} p<0.05$ vs EGFR in wt cells; ${ }^{\# \#} p<0.05$ vs ANF in wt cells).

alone as a control condition. After $24 \mathrm{~h}$ of transfection, cells were fixed and immunostained against BDNF and htt. Cells transfected with FL-17Q-htt or FL-75Q-htt were selected because of an increased immunoreactivity for anti-htt antibody. An enhanced colocalization of BDNF with GT-YFP was observed in the presence of FL-75Q-htt relative to FL-17Q-htt and the control condition. Moreover, we also performed the same colocalization studies in striatal knock-in wt or mhtt cells with 111Q (Trettel et al., 2000). mhtt cells showed increased colocalization of BDNF with giantin with respect to wt cells (Fig. 1) (supplemental Fig. 5, available at www.jneurosci.org as supplemental material).

\section{Val-BDNF but not Met-BDNF is retained at the Golgi apparatus in mhtt cells}

We next studied whether full-length htt differentially affects ValBDNF or Met-BDNF trafficking because expression of FL-75Qhtt increased accumulation of endogenous BDNF in Golgi apparatus. Thus, we performed several colocalization studies between Val-BDNF or Met-BDNF fused to eGFP with a variety of endomembrane markers in striatal knock-in wt or mhtt cells. These cell lines express full-length htt or full-length mhtt at endogenous levels, reflecting the closest situation to HD patients. After $24 \mathrm{~h}$ of transfection, cells were fixed and immunostained with calnexin or giantin, which are well established markers of the endoplasmatic reticulum (ER) and the Golgi apparatus, respectively. The colocalization between Val-BDNF or Met-BDNF with calnexin in either wt or mhtt cells showed no differences (Fig. 2A), giving an averaged colocalization in all cases of $\sim 25 \%$ (Fig. $2 B$ ). Conversely, when the colocalization of Val-BDNF or Met-BDNF with 
giantin was analyzed (Fig. 2C), we found an increased colocalization of Val-BDNF in mhtt cells compared with wt cells up to $15 \%$. No significant differences in the Golgi colocalization were found between wt and mhtt cells expressing Met-BDNF, but both were significantly higher with respect to Val-BDNF in wt cells (Fig. 2D).

mhtt differentially impairs post-Golgi trafficking of Val-BDNF and Met-BDNF To verify whether the different accumulation of Val-BDNF in the Golgi area was caused by an impaired post-Golgi transport, we performed FRAP studies. For FRAP studies, the Golgi area was marked and photobleached, and the recovery of Golgi fluorescence was monitored by time lapse until a plateau was reached (Fig. 3A). A fast increase in the Golgi fluorescence recovery was detected during the first $60 \mathrm{~s}$, reflecting the transport of new fluorescent proteins from the ER to the Golgi apparatus (Fig. 3B). No differences were observed in the transport of Val-BDNF or MetBDNF from the ER to the Golgi apparatus in wt or mhtt cells, showing similar kinetics values in all conditions (Table $1 A$ ). Nonetheless, the analysis of the total fluorescence recovery showed a $25 \%$ reduction of Val-BDNF post-Golgi trafficking in mhtt cells compared with wt cells (Fig. $3 A$ ), which is indicative of a reduced mobile fraction (Table $1 A$ ). In addition, the effects of mhtt in Met-BDNF trafficking were different from those obtained for Val-BDNF. Interestingly, no differences were observed between wt or mhtt cells expressing Met-BDNF. Moreover, wt cells expressing Met-BDNF showed a reduced Golgi fluorescence recovery compared with wt cells expressing Val-BDNF. Altogether, these results are indicative of an impaired post-Golgi trafficking of MetBDNF compared with Val-BDNF in wt cells.

Next, we performed iFRAP studies to verify the alteration of post-Golgi trafficking of Val-BDNF in mhtt cells (supplemental Movie 1, available at www.jneurosci.org as supplemental material). For iFRAP studies, Val-BDNF and Met-BDNF proteins were accumulated in the Golgi apparatus as described in Materials and Methods. Afterward, the entire cytoplasmic area, except the Golgi region, was photobleached, making possible the determination of the protein fraction leaving the Golgi region as the percentage of Golgi fluorescence decay. Val-BDNF expressed in mhtt cells showed a 33\% reduction in the Golgi exit compared with wt cells (Fig. 3C). No differences were observed between wt and mhtt cells expressing Met-BDNF, although both showed an altered post-Golgi trafficking when compared with Val-BDNF-expressing wt cells (Fig. 3C, Table $1 B$ ). These results strongly suggest that mhtt impairs postGolgi trafficking of Val-BDNF.

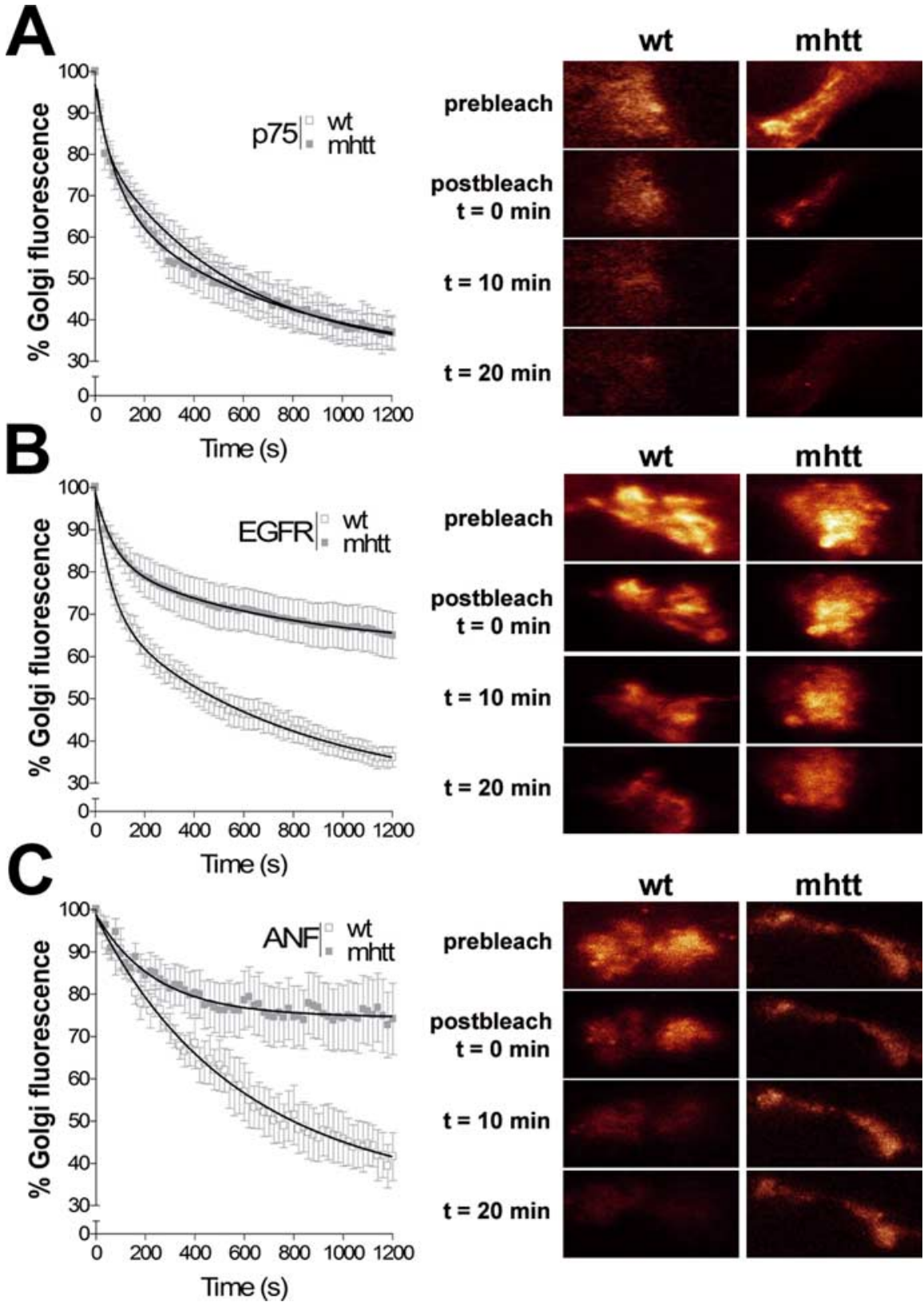

Figure 4. mhtt impairs the post-Golgi transport to the regulated pathway. $\boldsymbol{A}$, No differences were observed in wt and mhtt cells expressing $\mathrm{p}^{\mathrm{NTR}}{ }^{\mathrm{NTR}}$. EGFR $(\boldsymbol{B})$ and ANF $(\boldsymbol{C})$ showed an impaired post-Golgi transport in mhtt cells compared with wt cells. Representative Golgi apparatus fluorescence for each condition is shown on the right side. Results are represented as a mean \pm SEM determined from analysis of three independent experiments. $p<0.001$ for ANF and EGFR in mhtt versus wt cells.

To find out whether mhtt-induced post-Golgi transport impairment is restricted to Val-BDNF or whether it is also involved in post-Golgi transport in general, we examined a variety of cargo proteins exiting from the TGN in route to the plasma membrane. Thus, $\mathrm{p} 75^{\mathrm{NTR}}$ receptor, which exits TGN via constitutive pathway (De Lisle and Bansal, 1996), showed the same post-Golgi traffic kinetics in both wt and mhtt cells (Fig. $4 A$, Table $1 B$ ) (supplemental Movie 2, available at www.jneurosci.org as supplemental material). Conversely, the EGFR, which follows the constitutive and clathrin-dependent post-Golgi pathways (Willingham and Pastan, 1982; Sorkina et al., 1999), showed a $44 \%$ reduction in its post-Golgi trafficking in mhtt cells (Fig. 4B) (supplemental Movie 3, available at www.jneurosci.org as supplemental material). Accordingly, colocalization data of endoge- 


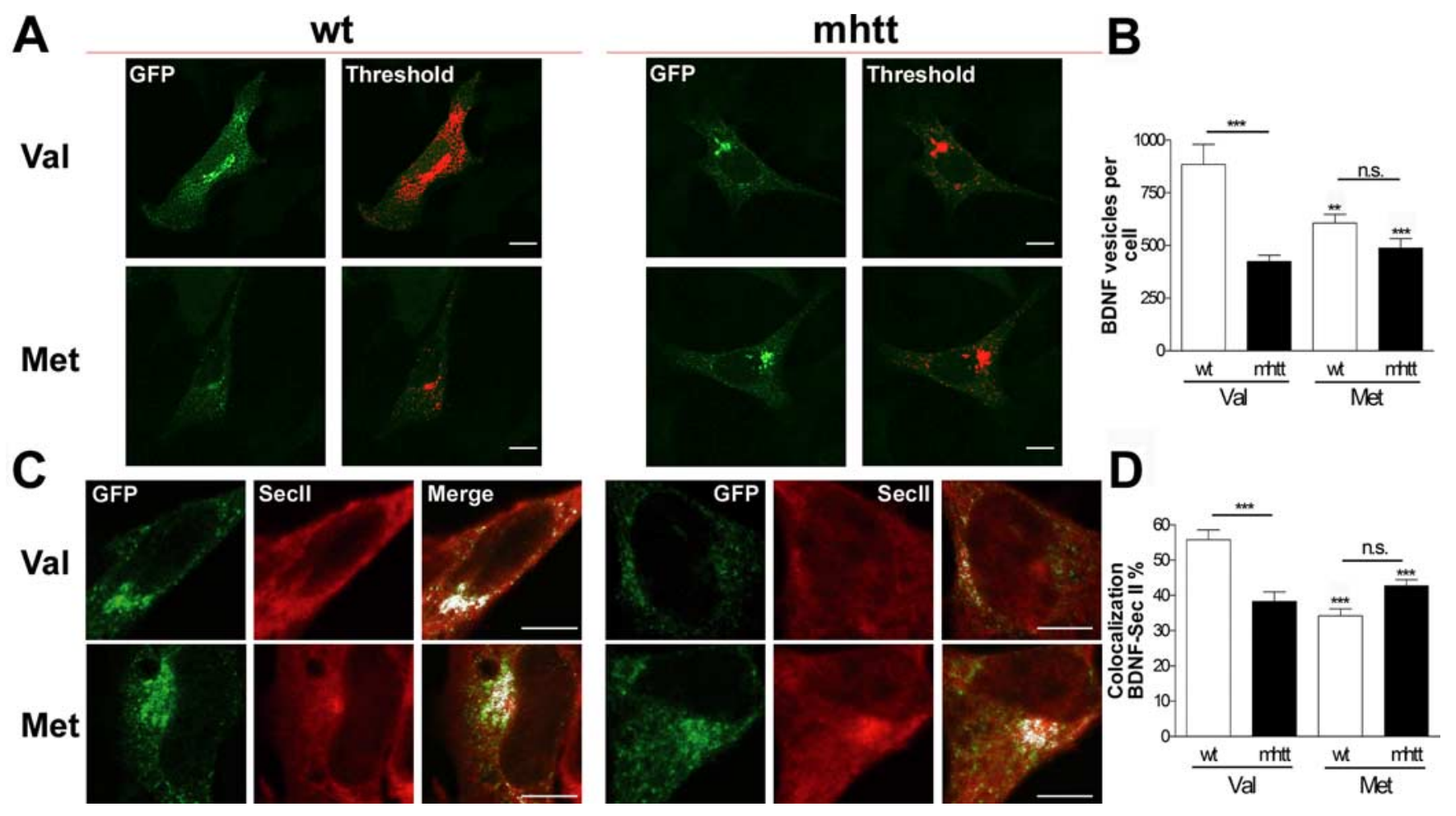

Figure 5. mhtt reduces the number of Val-BDNF but not Met-BDNF vesicles. A, For counting BDNF-containing vesicles, each stack of images was thresholded, and BDNF staining was marked in red. $\boldsymbol{B}$, All of the marked spots comprising 2-10 pixels were counted, showing a reduction in Val-BDNF-containing vesicles in mhtt cells compared with wt cells. $\boldsymbol{C}$, Colocalization between Val-BDNF or Met-BDNF and secretogranin II (Secll). D, Val-BDNF in mhtt cells showed a reduced colocalization with secretogranin II compared with wt cells. Results are represented as a mean \pm SEM determined from analysis of three independent experiments [not significant (n.s.), $p>0.05 ;{ }^{* *} p<0.01 ;{ }^{* * *} p<0.001$ vs Val-BDNF in wt cells). Scale bar, $8 \mu \mathrm{m}$.

nous EGFR and giantin showed an accumulation of EGFR in the Golgi of mhtt cells $(7.93 \pm 0.9 \%)$ compared with wt cells $(2.81 \pm$ $0.38 \%$ ) (supplemental Fig. 6, available at www.jneurosci.org as supplemental material). The ANF, which exits TGN by the regulated pathway (Bloch et al., 1986; De Young et al., 1994), showed a higher decrease $(60 \%)$ in its post-Golgi trafficking in mhtt cells compared with wt cells (Fig. 4C) (supplemental Movie 4, available at www. jneurosci.org as supplemental material).

\section{mhtt reduces the number of Val-BDNF- but not}

\section{Met-BDNF-containing vesicles}

To analyze the impaired post-Golgi traffic of Val-BDNF in mhtt cells, we next measured the total number of BDNF-containing vesicles produced per cell $24 \mathrm{~h}$ after transfection. Because in our images one pixel represents $54 \mathrm{~nm}$, we considered a vesicle those fluorescent spots comprising between 2 and 10 pixels (both included, $108-540 \mathrm{~nm}$ ) (Fig. $5 \mathrm{~A}$ ). We found a $50 \%$ reduction in the number of Val-BDNF-containing vesicles in mhtt cells. In contrast, no significant differences in the number of Met-BDNFcontaining vesicles were found between wt and mhtt cells. However, in both cells, the number of Met-BDNF vesicles was lower than Val-BDNF in wt cells (Fig. 5B). In addition, the colocalization of Val-BDNF with secretogranin II, which is a specific marker of secretory vesicles, was higher in wt cells than in mhtt cells (Fig. 5C), whereas no differences were observed between wt and mhtt cells expressing Met-BDNF (Fig. 5D), although they showed a reduced colocalization with secretogranin II compared with wt cells expressing Val-BDNF.

Val-BDNF and Met-BDNF-containing vesicles show similar transport dynamics in knock-in striatal cells

To determine a possible differential effect of mhtt in the transport of Val-BDNF or Met-BDNF vesicles, we next examined the dy- namics of BDNF-containing vesicles using confocal video microscopy. All Val-BDNF- or Met-BDNF-containing transport vesicles in either wt or mhtt cells were selected and tracked (Fig. $6 \mathrm{~A}$ ). We found an increase up to $16 \%$ for Val-BDNF and $24 \%$ for Met-BDNF in the number of vesicles with velocities between 0 and $30 \mu \mathrm{m} / \mathrm{min}$ in mhtt cells compared with wt cells, followed by a drastic decrease in the number of vesicles with velocities higher than $30 \mu \mathrm{m} / \mathrm{min}$ (Fig. $6 \mathrm{~B}$ ). Consequently, the overall mean velocity of Val-BDNF and Met-BDNF vesicles in mhtt cells was significantly lower $(18.1 \pm 2.54$ and $20.4 \pm 0.74 \mu \mathrm{m} / \mathrm{min}$, respectively) compared with wt cells $(24.53 \pm 1.1$ and $28.20 \pm 3.1$ $\mu \mathrm{m} / \mathrm{min}$, respectively). Moreover, these overall mean velocities are in agreement with previous studies (Kohara et al., 2001; Gauthier et al., 2004; Adachi et al., 2005). The fact that mhtt reduces the velocity of each vesicle was also observed when the diffusion pattern was calculated (Fig. 6C) (see Materials and Methods). Val-BDNFand Met-BDNF-containing vesicles showed the same pattern of diffusion in wt cells, and the diffusion of both Val-BDNF and MetBDNF vesicles was similarly reduced in mhtt cells.

mhtt preferentially reduces regulated secretion of Val-BDNF compared with Met-BDNF

Next, we assessed in striatal knock-in cells the constitutive and regulated secretion of Val-BDNF and Met-BDNF. There were no differences in the amount of BDNF released by constitutive secretion between Val-BDNF or Met-BDNF in either wt and mhtt cells. However, mhtt cells secreted $\sim 10 \%$ less Val-BDNF and Met-BDNF compared with wt cells (Fig. 7A).

Nevertheless, during cell depolarization ( $56 \mathrm{~mm} \mathrm{KCl}$ ), we found a drastic reduction of a $48 \%$ in the release of Val-BDNF expressed in mhtt cells with respect to wt cells expressing Val- 
BDNF. In contrast, mhtt only reduced $20 \%$ of the evoked secretion of Met-BDNF (Fig. 7B).

\section{Discussion}

Although htt has been related to diverse processes, its biological function has not been completely elucidated (Harjes and Wanker, 2003). Here, we show that fulllength, but not exon1, mhtt increases the accumulation of endogenous BDNF in the Golgi apparatus. Moreover, we also demonstrate that mhtt affects the trafficking to the regulated secretory pathway of ValBDNF with low effect on Met-BDNF, suggesting that htt has an important role in the post-Golgi transport of BDNF. These data provide new insights into the intracellular transport defect of BDNF associated with HD.

Our experiments showed that fulllength, but not exon 1, mhtt is required to induce an effect on BDNF post-Golgi trafficking. This effect could be explained by several protein interactions that are lost in the case of exon 1 htt. In fact, previous studies have shown that exon 1 htt does not modify BDNF transport because it cannot bind HAP1 (Gauthier et al., 2004).

Next we studied whether mhtt affects differentially Val-BDNF or Met-BDNF forms. It has been shown that Met-BDNF has an impaired sorting to the regulated secretory pathway with respect to ValBDNF because of a reduced interaction with sortilin at the TGN (Egan et al., 2003; Chen et al., 2004). Nonetheless, the reduced sorting of Met-BDNF to the regulated secretory pathway was not accompanied by an increase in the constitutive secretion (Chen et al., 2004, 2005). According to these results, we show that Met$\mathrm{BDNF}$ is retained in the Golgi apparatus compared with Val-BDNF in wt cells. However, we observed no differences in the trafficking from the ER to the Golgi apparatus. Colocalization studies using calnexin and FRAP experiments show that the presence of mhtt does not impair the transport of either Val-BDNF or Met-BDNF from ER to Golgi apparatus. This result is in agreement with a previous report suggesting that the trafficking between the ER and the Golgi in mhtt cells might not be affected compared with wt cells (Trettel et al., 2000). In contrast, we found that the post-Golgi trafficking of Val-BDNF was significantly blocked in mhtt cells, whereas mhtt did not produce a major retention of Met-BDNF in the Golgi apparatus. These findings, corroborated by colocalization studies with giantin and FRAP/iFRAP analyses, suggest that the effect of mhtt on the post-Golgi trafficking might be subsequent to the BDNF sorting. In addition, the results are indicative that htt seems to be involved in the post-Golgi-regulated pathway. To study this hypothesis, we analyzed the effect of mhtt on the trafficking of P75 ${ }^{\mathrm{NTR}}$, a protein that exits the TGN via the constitutive pathway (De Lisle and Bansal, 1996), EGFR, which follows both constitutive and clathrin-dependent pathways
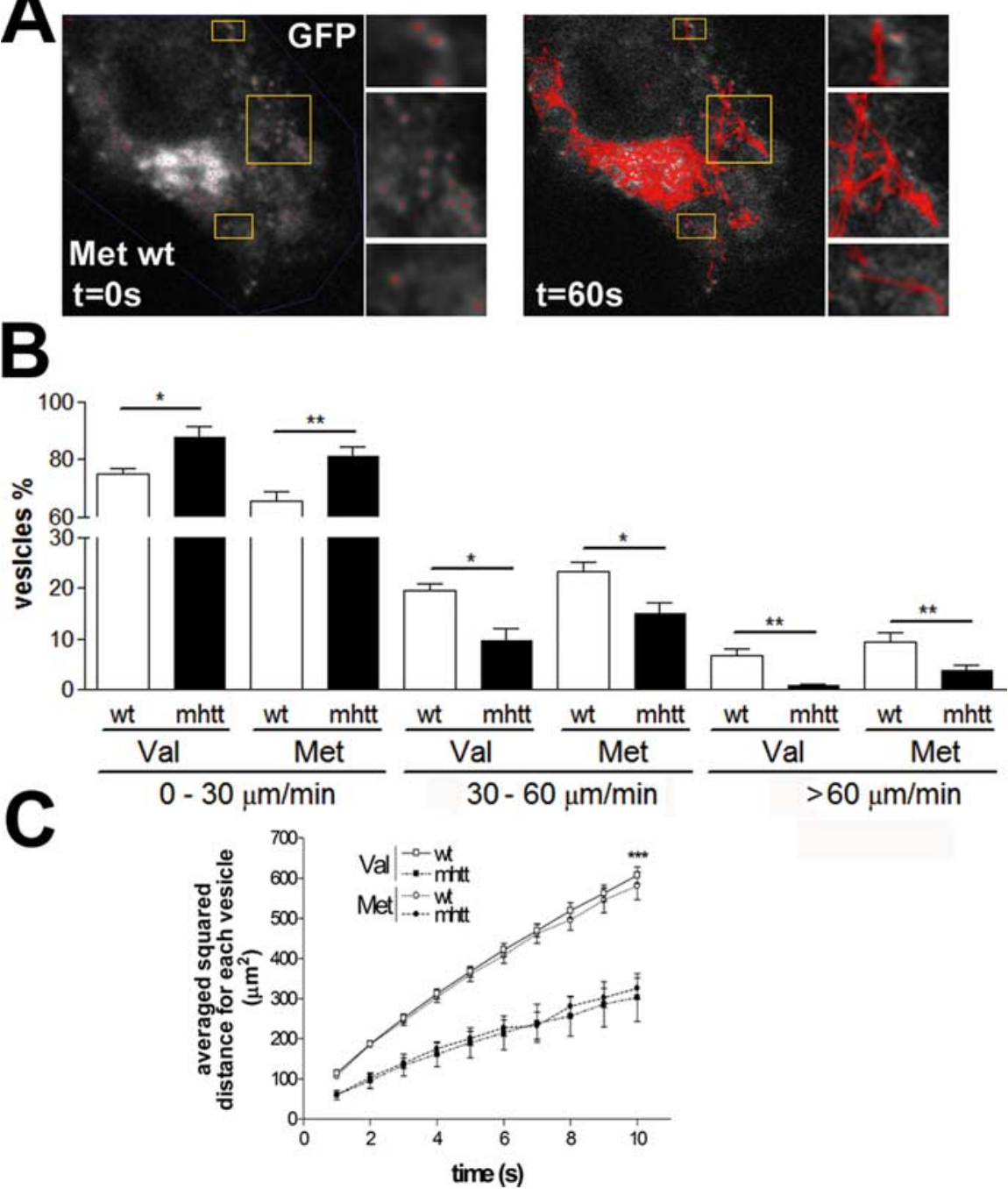

Figure 6. Val-BDNF- and Met-BDNF-containing vesicles have similar transport dynamics. $\boldsymbol{A}$, All vesicles in each cell were

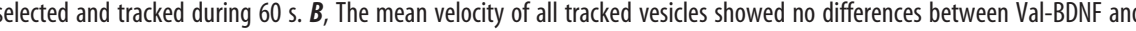
Met-BDNF vesicles. C, Val-BDNF- and Met-BDNF-containing vesicles showed the same pattern of diffusion in wt cells, which was 3761 measures; Met-BDNF in mhtt cells, 5177 measures. Results are represented as a mean \pm SEM determined from analysis of three independent experiments $\left({ }^{*} p<0.05 ;{ }^{* *} p<0.01\right.$; $\left.{ }^{* * *} p<0.001\right)$.

(Willingham and Pastan, 1982; Sorkina et al., 1999), and ANF, which is transported through regulated pathway (Bloch et al., 1986; De Young et al., 1994). iFRAP studies showed that mhtt does not affect the trafficking of P75 ${ }^{\mathrm{NTR}}$, but, in contrast, it impaired to a different extent the post-Golgi trafficking of EGFR and ANF. All of these data support a new role for htt in modulating the sorting and/or post-Golgi trafficking of different proteins. In accordance with this, mhtt only affects trafficking of proteins by the regulated pathway (Fig. 8). Another possibility, which is currently examined, is that mhtt may also disrupt the regulation of routing the EGFR to the lysosomal degradation pathway.

According to the results obtained about changes in post-Golgi trafficking, we observed that mhtt reduces the number of ValBDNF but not of Met-BDNF transport vesicles. The fact that wt cells expressing Met-BDNF produced less vesicles compared with wt cells expressing Val-BDNF is in agreement with previous studies reporting an altered intracellular trafficking of Met-BDNF producing less BDNF vesicles and therefore a reduced amount of secreted BDNF after neural cell depolarization (Chen et al., 


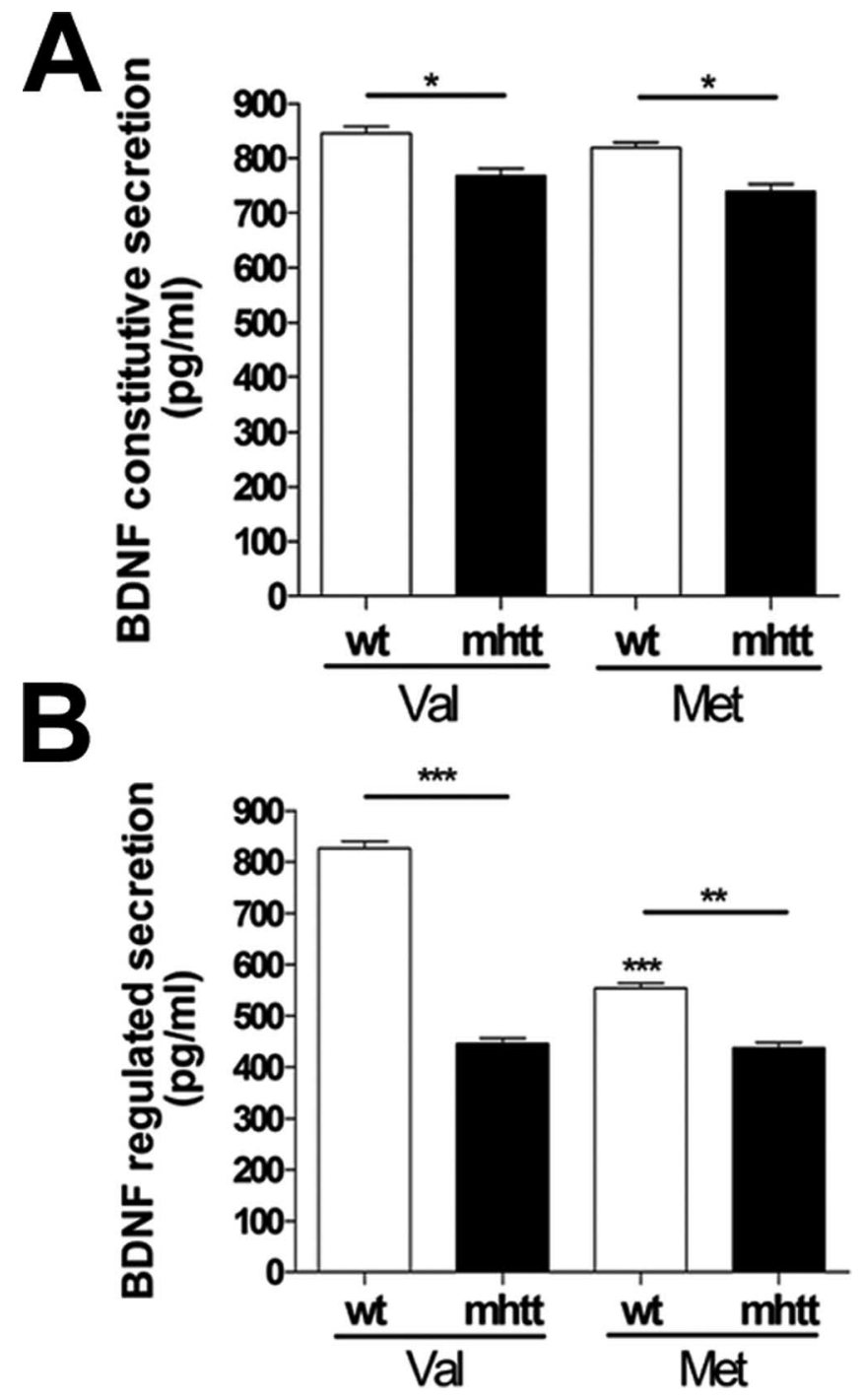

Figure 7. mhtt preferentially reduces regulated secretion of Val-BDNF compared with MetBDNF. Knock-in cells were transfected with dual-epitope-tagged BDNF constructs. After $24 \mathrm{~h}$, media was collected under constitutive $(\boldsymbol{A})$ and depolarization $(\boldsymbol{B})$ secretion conditions and analyzed by ELISA. Results are presented as a mean \pm SEM determined from analysis of three independent experiments $\left({ }^{*} p<0.05 ;{ }^{* *} p<0.01 ;{ }^{* * *} p<0.001\right.$ vs Val-BDNF in wt cells).

2004). However, mhtt equally impairs the transport dynamic properties of both Val-BDNF and Met-BDNF vesicles. These findings are in agreement with the role of htt in vesicle transport reported in previous studies by Gauthier et al. (2004). Thus, the effect of mhtt on the post-Golgi trafficking has a different functional repercussion on Val-BDNF or Met-BDNF release. mhtt cells showed a dramatic decrease in the $\mathrm{KCl}$-evoked release of Val-BDNF, whereas the impairment of Met-BDNF release during cell depolarization was very little. In contrast, the constitutive release of Val-BDNF and Met-BDNF was similarly affected by mhtt; this effect could be explained by a reduced transport of BDNF vesicles in their way to the plasma membrane, in accordance with previous studies (Gauthier et al., 2004).

All of these results localize the effect of mhtt on BDNF polymorphism at the Golgi apparatus level. Previous studies already linked htt with Golgi apparatus. Hence, the size of this perinuclear organelle is reduced by htt deficiency (Hilditch-Maguire et al., 2000). Furthermore, some htt-interacting proteins, such as HIP-14 (Singaraja et al., 2002) and HIP1R (Carreno et al., 2004),

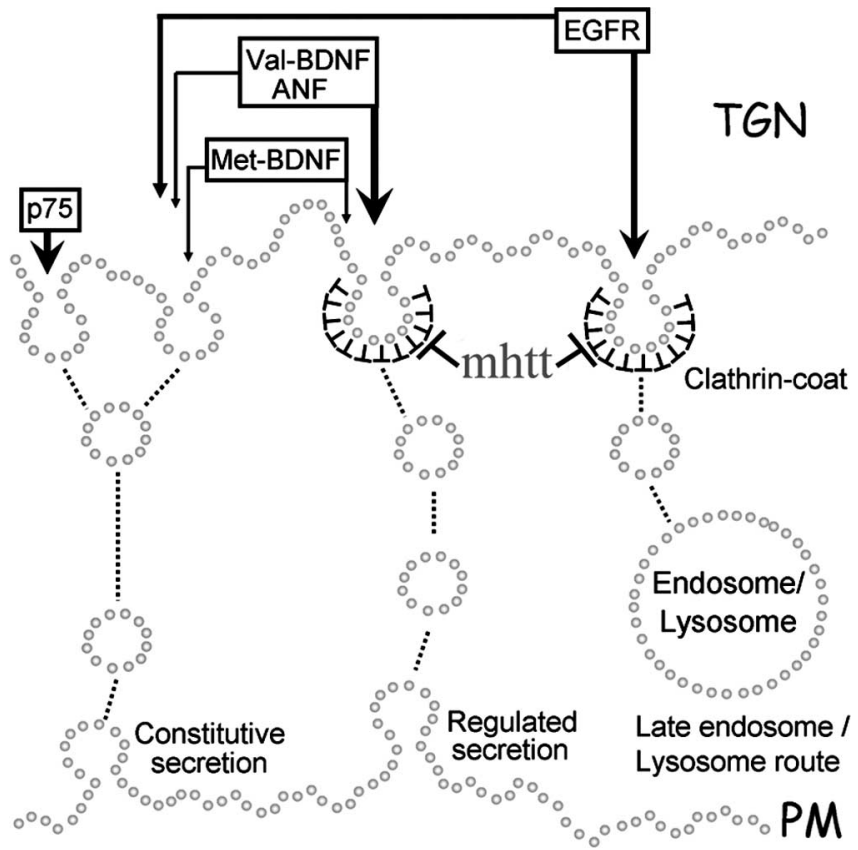

Figure 8. Schematic diagram of the effects of mhtt in post-Golgi trafficking of proteins depending on the secretory pathway. mhtt impairs trafficking of proteins secreted by the regulated clathrin-dependent pathway (Val-BDNF, EGFR, and ANF). In contrast, p75 and Met-BDNF were not severely affected. PM, Plasma membrane.

are located in Golgi apparatus. Therefore, it is reasonable to postulate that mhtt could induce aberrant interactions with proteins involved in post-Golgi sorting and trafficking (Egea et al., 2006). Our results also suggest that an incorrect folding attributable to the mutation of the prodomain of BDNF produces an accumulation of Met-BDNF in the Golgi apparatus. In fact, modeling of the prodomain on Val-BDNF and Met-BDNF shows that the substitution of valine to methionine at codon 66 might increase the prodomain stability, which leads to an altered interaction with sortilin (supplemental data and supplemental Fig. 7, available at www.jneurosci.org as supplemental material). However, additional experiments are required to confirm this hypothesis.

The findings of the present work and those reported previously (Chen et al., 2004, 2005) demonstrate that Val-BDNF and Met-BDNF differ in their post-Golgi trafficking in nonpathological cells. It has been estimated that $\sim 20-30 \%$ of the healthy human population is heterozygous for Met-BDNF (Egan et al., 2003; Sen et al., 2003; Alberch et al., 2005), and these people only exhibit a relatively low diminished memory performance (Hariri et al., 2003) and hippocampal volume (Szeszko et al., 2005), probably attributable to a reduced regulated secretion of MetBDNF. Nevertheless, this mutation in the BDNF prodomain is not associated with any neurological alteration per se.

A previous study showed that patients with HD carrying MetBDNF allele have a later age of onset compared with those carrying Val-BDNF (Alberch et al., 2005). However, it has been reported recently that there is no evidence of association between Met-BDNF and the age at onset of HD (Di Maria et al., 2006; Metzger et al., 2006), which could be related to the different origin population and/or size sample. In fact, differences in the influence of Met-BDNF has been described in different neurological disorders depending on the population analyzed (Ribases et al., 2004; Tochigi et al., 2006; Tsai et al., 2004; Green et al., 2006), suggesting that other factors can be involved (Rubinsztein et al., 1997; Wexler et al., 2004). 
In conclusion, our findings involve htt in post-Golgi transport regulation and that mhtt differently affects the post-Golgi transport of Val-BDNF and Met-BDNF, affecting more severely the regulated release of Val-BDNF compared with Met-BDNF. Thus, the Val66Met BDNF polymorphism supply different traffic support that could modulate the neurodegenerative process observed in HD.

\section{References}

Adachi N, Kohara K, Tsumoto T (2005) Difference in trafficking of brainderived neurotrophic factor between axons and dendrites of cortical neurons, revealed by live-cell imaging. BMC Neurosci 6:42.

Alberch J, Lopez M, Badenas C, Carrasco JL, Mila M, Munoz E, Canals JM (2005) Association between BDNF Val66Met polymorphism and age at onset in Huntington disease. Neurology 65:964-965.

Bloch KD, Seidman JG, Naftilan JD, Fallon JT, Seidman CE (1986) Neonatal atria and ventricles secrete atrial natriuretic factor via tissue-specific secretory pathways. Cell 47:695-702.

Burke NV, Han W, Li D, Takimoto K, Watkins SC, Levitan ES (1997) Neuronal peptide release is limited by secretory granule mobility. Neuron 19:1095-1102.

Canals JM, Pineda JR, Torres-Peraza JF, Bosch M, Martin-Ibanez R, Munoz MT, Mengod G, Ernfors P, Alberch J (2004) Brain-derived neurotrophic factor regulates the onset and severity of motor dysfunction associated with enkephalinergic neuronal degeneration in Huntington's disease. J Neurosci 24:7727-7739.

Carreno S, Engqvist-Goldstein AE, Zhang CX, McDonald KL, Drubin DG (2004) Actin dynamics coupled to clathrin-coated vesicle formation at the trans-Golgi network. J Cell Biol 165:781-788.

Carter RE, Sorkin A (1998) Endocytosis of functional epidermal growth factor receptor-green fluorescent protein chimera. J Biol Chem 273:35000-35007.

Cattaneo E, Zuccato C, Tartari M (2005) Normal huntingtin function: an alternative approach to Huntington's disease. Nat Rev Neurosci 6:919-930

Chen ZY, Patel PD, Sant G, Meng CX, Teng KK, Hempstead BL, Lee FS (2004) Variant brain-derived neurotrophic factor (BDNF) (Met66) alters the intracellular trafficking and activity-dependent secretion of wildtype BDNF in neurosecretory cells and cortical neurons. J Neurosci 24:4401-4411.

Chen ZY, Ieraci A, Teng H, Dall H, Meng CX, Herrera DG, Nykjaer A, Hempstead BL, Lee FS (2005) Sortilin controls intracellular sorting of brainderived neurotrophic factor to the regulated secretory pathway. J Neurosci 25:6156-6166.

De Lisle RC, Bansal R (1996) Brefeldin A inhibits the constitutive-like secretion of a sulfated protein in pancreatic acinar cells. Eur J Cell Biol 71:62-71.

De Young MB, Keller JC, Graham RM, Wildey GM (1994) Brefeldin A defines distinct pathways for atrial natriuretic factor secretion in neonatal rat atrial and ventricular myocytes. Circ Res 74:33-40.

Di Maria E, Marasco A, Tartari M, Ciotti P, Abbruzzese G, Novelli G, Bellone E, Cattaneo E, Mandich P (2006) No evidence of association between BDNF gene variants and age-at-onset of Huntington's disease. Neurobiol Dis 24:274-279.

Dundr M, Hoffmann-Rohrer U, Hu Q, Grummt I, Rothblum LI, Phair RD, Misteli T (2002) A kinetic framework for a mammalian RNA polymerase in vivo. Science 298:1623-1626.

Egan MF, Kojima M, Callicott JH, Goldberg TE, Kolachana BS, Bertolino A, Zaitsev E, Gold B, Goldman D, Dean M, Lu B, Weinberger DR (2003) The BDNF val66met polymorphism affects activity-dependent secretion of BDNF and human memory and hippocampal function. Cell 112:257-269.

Egea G, Lazaro-Dieguez F, Vilella M (2006) Actin dynamics at the Golgi complex in mammalian cells. Curr Opin Cell Biol 18:168-178.

Ferrer I, Goutan E, Marin C, Rey MJ, Ribalta T (2000) Brain-derived neurotrophic factor in Huntington disease. Brain Res 866:257-261.

Friedel S, Horro FF, Wermter AK, Geller F, Dempfle A, Reichwald K, Smidt J, Bronner G, Konrad K, Herpertz-Dahlmann B, Warnke A, Hemminger U, Linder M, Kiefl H, Goldschmidt HP, Siegfried W, Remschmidt H, Hinney A, Hebebrand J (2005) Mutation screen of the brain derived neurotrophic factor gene (BDNF): identification of several genetic variants and association studies in patients with obesity, eating disorders, and attention-deficit/hyperactivity disorder. Am J Med Genet B Neuropsychiatr Genet 132:96-99.

Gauthier LR, Charrin BC, Borrell-Pages M, Dompierre JP, Rangone H, Cordelieres FP, De MJ, MacDonald ME, Lessmann V, Humbert S, Saudou F (2004) Huntingtin controls neurotrophic support and survival of neurons by enhancing BDNF vesicular transport along microtubules. Cell 118:127-138.

Giordano M, Takashima H, Herranz A, Poltorak M, Geller HM, Marone M, Freed WJ (1993) Immortalized GABAergic cell lines derived from rat striatum using a temperature-sensitive allele of the SV40 large T antigen. Exp Neurol 124:395-400.

Green EK, Raybould R, Macgregor S, Hyde S, Young AH, O'Donovan MC, Owen MJ, Kirov G, Jones L, Jones I, Craddock N (2006) Genetic variation of brain-derived neurotrophic factor (BDNF) in bipolar disorder: case-control study of over 3000 individuals from the UK. Br J Psychiatry 188:21-25.

Hall D, Dhilla A, Charalambous A, Gogos JA, Karayiorgou M (2003) Sequence variants of the brain-derived neurotrophic factor (BDNF) gene are strongly associated with obsessive-compulsive disorder. Am J Hum Genet 73:370-376.

Hariri AR, Goldberg TE, Mattay VS, Kolachana BS, Callicott JH, Egan MF, Weinberger DR (2003) Brain-derived neurotrophic factor val66met polymorphism affects human memory-related hippocampal activity and predicts memory performance. J Neurosci 23:6690-6694.

Harjes P, Wanker EE (2003) The hunt for huntingtin function: interaction partners tell many different stories. Trends Biochem Sci 28:425-433.

Hilditch-Maguire P, Trettel F, Passani LA, Auerbach A, Persichetti F, MacDonald ME (2000) Huntingtin: an iron-regulated protein essential for normal nuclear and perinuclear organelles. Hum Mol Genet 9:2789-2797.

Kohara K, Kitamura A, Morishima M, Tsumoto T (2001) Activitydependent transfer of brain-derived neurotrophic factor to postsynaptic neurons. Science 291:2419-2423.

Kremer B, Goldberg P, Andrew SE, Theilmann J, Telenius H, Zeisler J, Squitieri F, Lin B, Bassett A, Almqvist E (1994) A worldwide study of the Huntington's disease mutation. The sensitivity and specificity of measuring CAG repeats. N Engl J Med 330:1401-1406.

Metzger S, Bauer P, Tomiuk J, Laccone F, Didonato S, Gellera C, Mariotti C, Lange HW, Weirich-Schwaiger H, Wenning GK, Seppi K, Melegh B, Havasi V, Baliko, Wieczorek S, Zaremba J, Hoffman-Zacharska D, Sulek A, Basak AN, Soydan E, et al. (2006) Genetic analysis of candidate genes modifying the age-at-onset in Huntington's disease. Hum Genet 120:285-292.

Momose Y, Murata M, Kobayashi K, Tachikawa M, Nakabayashi Y, Kanazawa I, Toda T (2002) Association studies of multiple candidate genes for Parkinson's disease using single nucleotide polymorphisms. Ann Neurol 51:133-136.

Phair RD, Misteli T (2000) High mobility of proteins in the mammalian cell nucleus. Nature 404:604-609.

Ribases M, Gratacos M, Armengol L, de CR, Badia A, Jimenez L, Solano R, Vallejo J, Fernandez F, Estivill X (2003) Met66 in the brain-derived neurotrophic factor (BDNF) precursor is associated with anorexia nervosa restrictive type. Mol Psychiatry 8:745-751.

Ribases M, Gratacos M, Fernandez-Aranda F, Bellodi L, Boni C, Anderluh M, Cristina Cavallini M, Cellini E, Di Bella D, Erzegovesi S, Foulon C, Gabrovsek M, Gorwood P, Hebebrand J, Hinney A, Holliday J, Hu X, Karwautz A, Kipman A, Komel R, et al. (2004) Association of BDNF with anorexia, bulimia and age of onset of weight loss in six European populations. Hum Mol Genet 13:1205-1212.

Rubinsztein DC, Leggo J, Chiano M, Dodge A, Norbury G, Rosser E, Craufurd D (1997) Genotypes at the GluR6 kainate receptor locus are associated with variation in the age of onset of Huntington disease. Proc Natl Acad Sci USA 94:3872-3876.

Ryder EF, Snyder EY, Cepko CL (1990) Establishment and characterization of multipotent neural cell lines using retrovirus vector-mediated oncogene transfer. J Neurobiol 21:356-375.

Seidah NG, Benjannet S, Pareek S, Savaria D, Hamelin J, Goulet B, Laliberte J, Lazure C, Chretien M, Murphy RA (1996) Cellular processing of the nerve growth factor precursor by the mammalian pro-protein convertases. Biochem J 314:951-960.

Sen S, Nesse RM, Stoltenberg SF, Li S, Gleiberman L, Chakravarti A, Weder $\mathrm{AB}$, Burmeister M (2003) A BDNF coding variant is associated with the 
NEO personality inventory domain neuroticism, a risk factor for depression. Neuropsychopharmacology 28:397-401.

Singaraja RR, Hadano S, Metzler M, Givan S, Wellington CL, Warby S, Yanai A, Gutekunst CA, Leavitt BR, Yi H, Fichter K, Gan L, McCutcheon K, Chopra V, Michel J, Hersch SM, Ikeda JE, Hayden MR (2002) HIP14, a novel ankyrin domain-containing protein, links huntingtin to intracellular trafficking and endocytosis. Hum Mol Genet 11:2815-2828.

Skibinska M, Hauser J, Czerski PM, Leszczynska-Rodziewicz A, Kosmowska M, Kapelski P, Slopien A, Zakrzewska M, Rybakowski JK (2004) Association analysis of brain-derived neurotrophic factor (BDNF) gene Val66Met polymorphism in schizophrenia and bipolar affective disorder. World J Biol Psychiatry 5:215-220.

Sorkina T, Bild A, Tebar F, Sorkin A (1999) Clathrin, adaptors and eps15 in endosomes containing activated epidermal growth factor receptors. J Cell Sci 112:317-327.

Szeszko PR, Lipsky R, Mentschel C, Robinson D, Gunduz-Bruce H, Sevy S, Ashtari M, Napolitano B, Bilder RM, Kane JM, Goldman D, Malhotra AK (2005) Brain-derived neurotrophic factor val66met polymorphism and volume of the hippocampal formation. Mol Psychiatry 10:631-636.

Tochigi M, Otowa T, Suga M, Rogers M, Minato T, Yamasue H, Kasai K, Kato N, Sasaki T (2006) No evidence for an association between the BDNF Val66Met polymorphism and schizophrenia or personality traits. Schizophr Res 87:45-47.

Trettel F, Rigamonti D, Hilditch-Maguire P, Wheeler VC, Sharp AH, Persichetti F, Cattaneo E, MacDonald ME (2000) Dominant phenotypes produced by the HD mutation in STHdh(Q111) striatal cells. Hum Mol Genet 9:2799-2809.
Tsai SJ, Hong CJ, Liu HC, Liu TY, Hsu LE, Lin CH (2004) Association analysis of brain-derived neurotrophic factor Val66Met polymorphisms with Alzheimer's disease and age of onset. Neuropsychobiology 49:10-12.

Ventriglia M, Bocchio CL, Benussi L, Binetti G, Zanetti O, Riva MA, Gennarelli M (2002) Association between the BDNF 196 A/G polymorphism and sporadic Alzheimer's disease. Mol Psychiatry 7:136-137.

Wada I, Rindress D, Cameron PH, Ou WJ, Doherty JJ, Louvard D, Bell AW, Dignard D, Thomas DY, Bergeron JJ (1991) SSR alpha and associated calnexin are major calcium binding proteins of the endoplasmic reticulum membrane. J Biol Chem 266:19599-19610.

Wexler NS, Lorimer J, Porter J, Gomez F, Moskowitz C, Shackell E, Marder K, Penchaszadeh G, Roberts SA, Gayan J, Brocklebank D, Cherny SS, Cardon LR, Gray J, Dlouhy SR, Wiktorski S, Hodes ME, Conneally PM, Penney JB, Gusella J, et al. (2004) Venezuelan kindreds reveal that genetic and environmental factors modulate Huntington's disease age of onset. Proc Natl Acad Sci USA 101:3498-3503.

Willingham MC, Pastan IH (1982) Transit of epidermal growth factor through coated pits of the Golgi system. J Cell Biol 94:207-212.

Zuccato C, Ciammola A, Rigamonti D, Leavitt BR, Goffredo D, Conti L, MacDonald ME, Friedlander RM, Silani V, Hayden MR, Timmusk T, Sipione S, Cattaneo E (2001) Loss of huntingtin-mediated BDNF gene transcription in Huntington's disease. Science 293:493-498.

Zuccato C, Tartari M, Crotti A, Goffredo D, Valenza M, Conti L, Cataudella T, Leavitt BR, Hayden MR, Timmusk T, Rigamonti D, Cattaneo E (2003) Huntingtin interacts with REST/NRSF to modulate the transcription of NRSE-controlled neuronal genes. Nat Genet 35:76-83. 